\title{
Pengaruh Persepsi Kemudahan, Kepercayaan dan Efektivitas terhadap Minat Menggunakan Financial Technology (Fintech) \\ (Studi Kasus: UMKM di Kabupaten Bantul)
}

\section{The Effect of Easy Perception, Trust and Effectiveness on Interest Using Financial Technology (Fintech) \\ (Case Study: SMEs in Bantul District)}

\author{
Akhnes Noviyanti ${ }^{1}$, Teguh Erawati² \\ ${ }^{1}$ Universitas Sarjanawiyata Tamansiswa - Yogyakarta \\ ${ }^{2}$ Universitas Sarjanawiyata Tamansiswa - Yogyakarta \\ Email: akhnes.noviyanti13@gmail.com
}

\begin{abstract}
ABSTRAK
Financial Technology (fintech) merupakan layanan keuangan yang memanfaatkan teknologi dalam pemakaiannya. Perkembangan teknologi yang cukup pesat menyebabkan munculnya banyak inovasi pada layanan keuangan. Kemudahan dan manfaat yang diberikan akan mempermudah aktivitas penggunanya. Penelitian ini bertujuan untuk mengetahui berbagai macam persepsi yang dapat mempengaruhi minat seseorang dalam menggunakan financial technology (fintech), penelitian ini menggunakan metode kuantitatif, data berasal dari pelaku UMKM di Kabupaten Bantul tahun 2020 dengan jumlah responden 100. Data diolah dengan menggunakan uji asumsi klasik dan uji hipotesis dengan Uji T, Uji F dan uji Determinasi. Hasil penelitian membuktikan bahwa persepsi kemudahan berpengaruh positif terhadap minat menggunakan financial technology (fintech) sebesar 29,2\%. Pengaruh kepercaaan berpengaruh negatif terhadap minat menggunakan financial technology (fintech) sebesar $11,8 \%$ dan efektivitas berpengaruh positif terhadap minat menggunakan financial technology (fintech) sebesar 58,7\%.

Kata Kunci: Fintech, Persepsi Kemudahan, Kepercayaan, Efektivitas, Minat, UMKM
\end{abstract}

\begin{abstract}
Financial Technology (fintech) is a financial service that utilizes technology in its use. The rapid development of technology has led to many innovations in financial services. The convenience and benefits provided will facilitate user activities. This study aims to determine the various kinds of perceptions that can affect a person's interest in using financial technology (fintech), this research uses quantitative methods, the data comes from SMEs players in Bantul Regency in 2020 with 100 respondents. The data is processed using classical assumption tests and Hypothesis test with $T$ test, $F$ test and Determination test. The results of the study prove that the perceived ease of use has a positive effect on the interest in using financial technology (fintech) by $29.2 \%$. The influence of scolding has a negative effect on the interest in using financial technology (fintech) by $11.8 \%$ and the effectiveness has a positive effect on the interest in using financial technology (fintech) by $58.7 \%$.
\end{abstract}

Keywords: Fintech, Perceived Ease, Trust, Effectiveness, Interest, SMEs 


\section{PENDAHULUAN}

Perkembangan teknologi digital sangatlah pesat, banyak inovasi baru yang bermunculan di bidang teknologi ini, mulai dari software hingga hardware serta perangkat pendukung lainnya. Perkembangan teknologi digital didukung dengan penggunaan gadget dan internet yang juga mengalami peningkatan, anak-anak hingga orang dewasa pun menggunakannya. Menurut hasil survei yang dilakukan oleh Asosiasi Penyelenggara Jasa Internet Indonesia (APJII) bahwa pengguna internet di Indonesia sebanyak 143,26 juta jiwa atau sebesar $54,68 \%$ dari total penduduk Indonesia. Semakin berkembangnya zaman, teknologi saat ini tidak hanya digunakan pada sektor pendidikan, sosial, politik, namun sudah mulai menjalar pada sektor perekonomian. Perkembangan ini ditandai dengan adanya teknologi keuangan atau disebut financial technology (fintech). Fintech mengacu pada inovasi yang mengarah pada teknologi keuangan seperti perbankan, pinjaman dan lain sebagainya. Penerapan teknologi informasi (financial technology) pada bidang keuangan sangat membantu gaya hidup sosial, yang dulunya manual dan membutuhkan waktu yang lama pada saat proses transaksi serta pertukaran data informasi, sekarang menjadi serba efisien tanpa memerlukan waktu lama (Arif, Fatichatur 2019).

Kemunculan fintech berasal dari akibat perubahan gaya hidup masyarakat yang mayoritas menggunakan teknologi informasi serba cepat atau kilat. Fintech memberikan banyak solusi dan kemudahan (Rosalina, Handjoyo \& Wibowo, 2015). Penggunaan financial technologi (fintech) dapat dipengaruhi oleh beberapa persepsi seperti persepsi kemudahan, kepercayaan dan efektivitas terhadap penggunaannya. Persepsi kemudahan didefinisikan sebagai seberapa jauh seseorang mempercayai bahwa menggunakan teknologi akan terbebas dari usaha. Kemudahan dapat dikatakan kepercayaan tentang proses pengambilan keputusan. Jika individu percaya sistem informasi dengan mudah digunakan maka akan menggunakannya (Jogiyanto, 2007). Kepercayaan menurut Gilbert \& Tang (1998) mengacu pada keyakinan terhadap sesuatu serta percaya bahwa sesuatu hal yang dilakukan pada akhirnya akan membawa kebaikan atau keuntungan. Sedangkan efektivitas yaitu hasil yang diperoleh dari penggunaan suatu teknologi sesuai dengan tujuan penggunaanya. Oleh karena itu perlu adanya pemahaman lebih lanjut mengenai kemudahan yang diberikan fintech, menanamkan kepercayaan dan mengerti efektivitas yang akan dirasakan karena penggunaan fintech.

Usaha Mikro Kecil Menengah (UMKM) merupakan salah satu penunjang perekonomian negara. UMKM dapat mendorong pertumbuhan ekonomi serta menciptakan lapangan pekerjaan, sehingga sektor ini memiliki peran dalam menjaga stabilitas ekonomi (Irma, Inayah, Bella 2018). UMKM merupakan usaha yang tahan banting akan kegagalan usahanya. Namun, UMKM memiliki masalah utama yaitu pendanaan secara kredit untuk memiliki modal usaha, terlebih usaha mikro dan kecil di Indonesia terkendala dengan tidak adanya jaminan untuk mendapatkan kredit modal (Tedy, 2019).

Usaha Mikro Kecil dan Menengah (UMKM) sampai saat ini menjadi penopang utama perekonomian di Yogyakarta. Daya tahan yang dimiliki UMKM menjadikan pertumbuhan ekonominya tumbuh diatas ekonomi Indonesia. Kontribusi UMKM terhadap perekonomian Yogyakarta mencapai $94,6 \%$ dan mampu menyerap 79\% total lapangan kerja, dari jumlah tersebut industri pengolahan, perdagangan serta perhotelan yang paling banyak menopang tenaga kerja (https://m.medcom.id/ekonomi/mikro/8N0V8mAk-umkm-dongkrak-pertumbuhanekonomi-yogyakarta-lampaui-nasional).

Berdasarkan survei Asian Development Bank pada Juni 2020, terlihat bahwa 90\% UMKM membutuhkan bantuan keuangan dimasa pandemi covid-19. Pandemi ini membuat banyak negara melakukan lockdown dan pembatasan, hal ini membuat para pelaku UMKM kesulitan 
dalam berjualan, terlebih UMKM yang mengandalkan bahan bakunya yang berasal dari luar negeri. Hal ini menjadikan momentum melesatnya fintech di Indonesia, para penyelenggaran fintech baik lending maupun pembayaran sangat ekspansif menjelang pandemi ini. Penggunaan fintech bukan hanya dalam porsi kecil atau mengisi kekosongan yang ditinggalkan bank, melainkan bisa menggantikan dari sistem keuangan konvensional.

Tujuan adanya penelitian ini yaitu untuk menganalisis seberapa besar pengaruh dari persepsi kemudahan, kepercayaan dan efektivitas terhadap penggunaan financial technology (fintech) pada pelaku UMKM yang berada di Kabupaten Bantul.

\section{LANDASAN TEORI}

\section{Financial Technology (Fintech)}

Menurut The National Digital Research Centre (NDRC), di Dublin, Irlandia, mendefinisikan fintech sebagai "innovation infinancial services" atau "inovasi dalam layanan keuangan fintech" yaitu suatu inovasi financial yang berbaur dengan teknologi modern. Fintech merupakan akses yang terbuka untuk jasa layanan keuangan formal, mendorong pertumbuhan ekonomi bangsa serta pembangunan inklusif dan berkelanjutan. Perpres no. 82 tahun 2016 menjelaskan tentang Strategi Keuangan Nasional Inklusif, bertujuan untuk menciptakan ekonomi yang mandiri dengan menggerakkan sektor strategis ekonomi domestik termasuk Usaha Mikro Kecil Menengah (UMKM) di Indonesia perlu dapat dorongan, khususnya pemerintah karena permasalahan permodalan adalah kendala UMKM di Indonesia.

Perkembangan teknologi keuangan di Indonesia memiliki dampak positif pada perekonomian Indonesia seperti mendorong pemerataan kesejahteraan penduduk, pembiayaan dalam negeri, pembiayaan nasional, inklusi keuangan nasional meningkat, serta mendorong UMKM yang berkemampuan rendah. Namun adaya pemerintah sebagai regulator ekonomi, harus memberdayakan masyarakat sampai ke perdesaan dan daerah terpencil agar dapat merasakan dampak positif dari adanya perkembangan teknologi di masa mendatang. Fintech sendiri memiliki beberapa jenis yang popular yaitu Crowdfunding dan Peer to Peer Lending $(P 2 P)$, Risk and Investment Management, Market Aggregator dan Payment, Clearing and Statement.

\section{Usaha Mikro Kecil Menengah (UMKM)}

Usaha Mikro Kecil Menengah (UMKM) adalah salah satu variabel yang dianggap penting dalam perekonomian sebuah negara. Sektor ini mampu menyokong pertumbuhan ekonomi serta mengurangi pengangguran dengan cara membuka lapangan pekerjaan, sehingga UMKM dapat dikatakan mampu menjaga kestabilitas ekonomi negara, semakin bertambahnya UMKM semakin besar penyerapan tenaga kerja yang dapat dilakukan.

Menurut Undang-Undang Nomor 20 Tahun 2008 UMKM diartikan sebagai usaha mikro, usaha kecil, usaha kecil dan menengah, usaha menengah dan wirausaha. Kriteria UMKM yang tertuang pada pasal 6 Undang-Undang Nomor 20 tahun 2008 tentang Usaha Mikro Kecil dan Menengah yaitu:

1. Kriteria Usaha Mikro. Usaha mikro memiliki kekayaan aset maksimal 50 juta termasuk tanah dan bangunan, mendapatkan hasil penjualan tahunan paling banyak 300 juta. 
2. Kriteria Usaha Kecil. Memiliki kekayaan berish maksimal $>50$ dan paling banyak 500 juta tidak termasuk tanah dan bangunan, memiliki hasil penjualan tahunan $>300$ juta $->3,5$ milyar.

3. Kriteria Usaha Menengah. Memiliki kriteria aset $>500$ juta $-10 \mathrm{M}$ dengan omset $>2,5 \mathrm{M}-50$ $\mathrm{M}$, memiliki hasil penjualan tahunan $>300$ juta sampai dengan $\mathrm{Rp} .2$ milyar lima ratus ribu rupiah.

\section{Theory of Planned Behavior (TPB)}

Teori ini dapat menjelaskan bahwa kepercayaan dapat mempengaruhi individu berminat atau mempunyai keinginan untuk menggunakan teknologi. Teori yang dikembangkan oleh Ajzen (1985) merupakan pengembangan teori lebih lanjut dari Theory of Reasoned Action (TRA). Theory of Planned Behavior (TPB) digunakan untuk memprediksi perilaku individu. Teori TPB merupakan pengembangan dari Theory of Reasoned Action (TRA), dalam TRA telah dijelaskan bahwa niat seseorang berperilaku berasal dari dua faktor yaitu attitude toward the behavior dan subjective norm (Fishbein dan Ajzen, 1975) sedangkan dalam TPB ditambahkan satu faktor yaitu perceived behavioral control (Ajzen 1991). Teori yang di kembangkan oleh Ajzen pada tahun 1991 digunakan untuk menjelaskan bahwasannya kepercayaan dapat mempengaruhi seseorang berminat untuk menggunakan suatu teknologi. Jogiyanto (2007) mengembangkan teori ini dengan menambahkan konstruk yang tidak ada dalam TRA yaitu perilaku persepsian (perceived behavioral control). Persepsi tersebut digunakan untuk menjelaskan situasi di mana individu tidak memiliki kendali atas perilaku yang diinginkan. Perilaku seseorang tidak hanya dipengaruhi oleh keinginan seseorang untuk berperilaku dan berpandangan tentang perilaku orang lain, namun dapat pula dipengaruhi oleh faktor lain seperti peluang, sumber daya dan lain sebagainya (Harrison et al, 1997).

\section{Technology Acceptance Model (TAM)}

Menurut Davis et al. (1989) salah satu teori yang dapat menjelaskan penerimaan individu dalam menggunakan teknologi adalah Technology Acceptence Model (TAM) yang dikenalkan oleh Fred D. Davis pada tahun 1989, model ini adalah pengembangan dari teori Theory of Planed Action (TRA) dan Theory Planned Behavior (TPB). Model ini dirancang untuk memprediksi penerimaan atau penggunaan teknologi oleh pengguna beserta manfaatnya dalam pekerjaan. Teori yang di kembangkan (Davis, 1989) menjadikan variabel persepsi manfaat (perceived usefulness) dan persepsi kemudahan penggunaan (perceived ease of use) sebagai alat ukur untuk mengalisis penerimaan individu terhadap penggunaan suatu teknologi. TAM bertujuan untuk menganalisis dan menjelaskan penerimaan individu terhadap penggunaan suatu teknologi. TAM menjelaskan hubungan sebab akibat antara keyakinan akan manfaat suatu sistem informasi dan kemudahan penggunaannya, perilaku tujuan/keperluan, penggunaan aktual dari pengguna/user suatu sistem informasi. TAM menjelaskan bahwa terdapat dua variabel yang mampu mempengaruhi individu dalam menghadapi teknologi untuk menggunakan atau tidak yaitu persepsi kemudahan dan persepsi kegunaan. Terdapat lima hal yang mendasari teori TAM (Jogiyanto, 2007) yaitu kegunaan persepsian (perceived usefulness), kemudahan persepsian (perceived ease of use), sikap terhadap perilaku (attitude towards behavior) atau sikap menggunakan teknologi (attitude towards using technology), minat perilaku menggunakan 
teknologi (behavioral intention to use), penggunaan teknologi sesungguhnya (actual technology use).

\section{Pengembangan Hipotesis}

\section{Persepsi Kemudahan Berpengaruh Positif Terhadap Minat Mengggunakan Financial Technology (Fintech).}

Jogiyanto (2007) menyatakan persepsi kemudahan didefinisikan sebagai seberapa jauh seseorang mempercayai bahwa menggunakan suatu teknologi akan terbebas dari usaha. Kemudahan merupakan komponen dari Technology Acceptence Model (TAM), model ini dirancang untuk memprediksi penerimaan atau penggunaan teknologi oleh pengguna beserta manfaatnya dalam pekerjaan (Davis et al, 1989). Davis menjadikan variabel persepsi manfaat dan persepsi kemudahan penggunaan sebagai alat ukur untuk menganalisis penerimaan individu terhadap penggunaan suatu teknologi. Persepsi kemudahan penggunaan didefinisikan sebagai bentuk di mana orang percaya bahwa teknologi informasi dapat dengan mudah dipahami (Davis, 1989).

Penggunaan financial technology yang mudah digunakan pasti akan digunakan oleh pelaku UMKM. Dalam Jogiyanto (2007) jika seseorang merasa atau meyakini bahwa sistem teknologi informasi mudah digunakan maka ia akan menggunakannya begitupun sebaliknya, jika sistem tidak mudah digunakan maka tidak akan menggunakannya. Hal ini sesuai dengan penelitian yang dilakukan oleh Wildan (2019) yang menyatakan bahwa kemudahan dan efektivitas berpengaruh positif dan signifikan terhadap minat bertransaksi menggunakan financial technology. Berdasarkan uraian diatas maka dapat diperoleh hipotesis seperti:

\section{H1: Persepsi kemudahan berpengaruh positif terhadap minat menggunaan financial technology}

\section{Kepercayaan Berpengaruh Positif Terhadap Minat Menggunakan Financial Technology (Fintech)}

Kepercayaan adalah keyakinan bahwa masing-masing pihak saling bergantung dan membutuhkan. Menurut Gilbert \& Tang (1998) kepercayaan mengacu pada keyakinan terhadap sesuatu serta percaya bahwa akhirnya apa yang dilakukan akan membawa kebaikan atau keuntungan

Theory of Planed Behavior (TPB) dapat menjelaskan bahwa kepercayaan dapat mempengaruhi individu mempunyai keinginan untuk menggunakan teknologi (Icck Ajzen, 1991). Ajzen menjelaskan bahwa kepercayaan dapat mempengaruhi seseorang berminat untuk menggunakan suatu teknologi. Kepercayaan berpengaruh positif terhadap minat menggunakan teknologi jenis financial technology, hal ini dibuktikan dalam penelitian Sandi (2018) dengan hasil kepercayaan berpengaruh positif terhadap minat menggunakan mobile money T-Cash pada mahasiswa jurusan perbankan syariah IAIN Surakarta, berdasarkan uraian tersebut maka dapat dirumuskan hipotesis sebagai berikut:

\section{H2: Kepercayaan Berpengaruh Positif Terhadap Minat Menggunakan Financial Technology}




\section{Efektivitas Berpengaruh Positif Terhadap Minat Menggunakan Financial Technology (Fintech)}

Efektivitas dapat didefinisikan sebagai daya guna, keaktifan, serta adanya kesesuaian dalam suatu kegiatan antara seseorang yang melaksanakan tugas dengan tujuan yang ingin dicapai. Menurut Davis 1989 persepsi kegunaan adalah suatu kepercayaan seseorang bahwa dengan menggunakan teknologi akan meningkatkan prestasi kerja mereka. Efektivitas yang dimaksud yaitu hasil yang diperoleh dari penggunaan suatu teknologi sesuai dengan tujuan penggunaanya. Persepsi kemudahan penggunaan merupakan komponen dari Technology Accaptance Model (TAM) yang berkaitan erat dengan efektivitas, ketika seseorang merasa percaya bahwa teknologi informasi mudah dipahami maka orang akan memiliki rasa percayaan bahwa menggunakan teknologi akan meningkatkan prestasi kerja mereka. Hal ini menunjukkan bahwa persepsi kegunaan sangat berkaitan dengan efektivitas, semakin banyak kegunaan yang didapatkan oleh penguna teknologi maka efektivitas penggunaannya dapat tercapai

Dugaan ini sesuai dengan penelitian yang dilakukan oleh Wildan (2019) yang menyatakan bahwa kemudahan dan efektivitas berpengaruh positif dan signifikan terhadap minat bertransaksi menggunakan financial technology. Berdasarkan uraian diatas maka dapat diperoleh hipotesis seperti:

\section{H3: Efektivitas Berpengaruh Positif Terhadap Minat Menggunakan Financial Technology}

\section{METODOLOGI PENELITIAN}

\section{Jenis dan Sumber Data Penelitian}

Jenis data yang digunakan dalam penelitian ini adalah data primer, yaitu data yang diperoleh langsung dari sumber pertama dilokasi penelitian atau objek penelitiian. Data yang diperoleh yaitu berupa kuisioner mengenai jawaban responden terhadap berbagai persepsi mengenai minat menggunakan financial technology (fintech). Populasi yang digunakan dalam penelitian ini yaitu semua pelaku UMKM yang berada di Kabupaten Bantul dengan pendapatan $\leq$ Rp.10.000.000 per bulan. Pengambilan sampel dilakukan dengan metode random sampling. Jumlah populasi pada tahun 2020 sejumlah 15.502 pelaku UMKM, penentuan jumlah responden dihitung dengan menggunakan rumus slovin sehingga repnden yang digunakan sebanyak 100 responden.

\section{Metode Analisis dan Hipotesisi Penelitian}

Pengujian yang dilakukan pertama yaitu dengan uji asumsi klasik. Uji asumsi klasik yang digunakan yaitu uji normalitas, uji linieritas, uji multikolinearitas dan uji heteroskedastisitas sebagai syarat untuk digunakannya uji regresi berganda. Kemudian metode analisis yang digunakan untuk menguji pengaruh variabel bebas terhadap variabel terikat yaitu dengan analisis regresi berganda, uji $\mathrm{T}$, uji F dan uji determinasi $\left(\mathrm{R}^{2}\right)$.

\section{Operasional Variabel Penelitian}

Variabel independen dapat diartikan sebagai variabel bebas yaitu variabel yang mempengaruhi perubahan variabel independen. Dalam penelitian ini yang menjadi variabel bebas yaitu persepsi kemudahan (X1), kepercayaan (X3) dan efektivitas (X3). 


\section{Persepsi Kemudahan (X1)}

Persepsi kemudahan penggunaan didefinisikan sebagai sejauh mana seseorang percaya bahwa menggunakan suatu teknologi akan bebas dari usaha (Jogiyanto, 2007) atau dapat diartikan pula keadaan dimana seseorang meyakini bahwa dengan menggunakan sistem tertentu tidak diperlukan usaha apapun (free of effort) (Davis, 1989). Terdapat indikator persepsi kemudahan penggunaan (perceived ease of use) yang ditemukan, menurut Chuang, et.al. (2016) terdapat empat indikator dari persepsi kemudahan penggunaan (perceived ease of use), yaitu persepsi fleksibilitas, persepsi kemudahan untuk berinteraksi, persepsi kemudahan untuk digunakan dan persepsi kemudahan untuk dipelajari.

\section{Kepercayaan (X2)}

Kepercayaan adalah keyakinan bahwa masing-masing pihak saling bergantung dan membutuhkan. Menurut Gilbert \& Tang (1998) kepercayaan mengacu pada keyakinan terhadap sesuatu serta percaya bahwa akhirnya apa yang dilakukan akan membawa kebaikan atau keuntungan. Menurut Mayer et al (1995), persepsi kepercayan dalam transaksi online didasarkan tiga faktor yaitu kemampuan (ability), kebaikan hati (benevolence) dan integritas (integrity).

\section{Efektivitas (X3)}

Efektivitas dapat diartikan sebagai daya guna, keaktifan, serta adanya kesesuaian dalam suatu kegiatan antara seseorang yang melaksanakan tugas dengan tujuan yang ingin dicapai. Menurut Davis 1989 persepsi kegunaan adalah suatu kepercayaan seseorang bahwa dengan menggunakan teknologi akan meningkatkan prestasi kerja mereka. Efektivitas yang dimaksud yaitu hasil yang diperoleh dari penggunaan suatu teknologi sesuai dengan tujuan penggunaanya. Berdasarkan pengertian tersebut persepsi kegunaan sangat berkaitan dengan efektivitas, semakin banyak kegunaan yang didapatkan oleh penguna teknologi maka efektivitas penggunaannya dapat tercapai. Persepsi kegunaan dapat dibagi menjadi beberapa dimensi yaitu penggunaan sistem dapat meningkatkan kinerja individu (improves job performance), peggunaan sistem dapat meningkatkan produktivitas individu (increase productivity), penggunaan sistem dapat meningkatkan efektivitas kinera individu (enchances effectivence) dan penggunaan sistem beranfaat bagi individu (the sistem is useful).

Variabel terikat adalah variabel yang mempengaruhi atau yang menjadi akibat karena adanya variabel bebas. Variabel terikat dalam penelitian ini yaitu minat menggunakan Financial technology (Y).

\section{Minat Mengggunakan Financial Technologi (Y)}

Financial technology (Fintech) atau teknologi finansial adalah implementasi dan pemanfaatan teknologi untuk meningkatkan layanan jasa perbankan dan keuangan atau layanan jasa keuangan yang memanfaatkan teknologi. Fintech didefinisikan sebagai "innovation infinancial services" atau "inovasi dalam layanan keuangan fintech" yaitu suatu inovasi financial yang berbaur dengan teknologi modern. minat diartikan sebagai ketertarikan seseorang atau individu dalam menggunakan financial technology. Minat dapat dipengaruhi oleh faktor internal ataupun eksternal. Ketika seseorang menyadari implikasi dari tindakannya menimpulkan hal positif maka orang tersebut akan mempertahankan minatnya (Jogiyanto, 2007). Untuk mengukur minat seseorang dapat menggunakan 
beberapa indikator yaitu rasa ingin menggunakan, selalu menggunakan dan berlanjut menggunakan dimasa yang akan datang (Jogiyanto, 2007).

\section{HASIL DAN PEMBAHASAN}

\section{Hasil Penelitian}

Pengujian hipotesis digunakan untuk membuktikan hasil penelitian berdasarkan hipotesis yang telah ditetapkan sebelumnya. Berikut tabel hasil uji hipotesis penelitian:

\section{Tabel. 1. Hasil Uji Regresi Berganda}

\section{Coefficients $^{\mathrm{a}}$}

\begin{tabular}{llrrrrr}
\hline Model & \multicolumn{2}{c}{$\begin{array}{c}\text { Unstandardized } \\
\text { Coefficients }\end{array}$} & $\begin{array}{c}\text { Standardized } \\
\text { Coefficients } \\
\text { B }\end{array}$ & \multicolumn{1}{c}{ T } & Sig. \\
& \multicolumn{1}{c}{ Std. Error } & \multicolumn{2}{c}{ Beta } & & \\
\hline (Constant) & -1.173 & 2.412 & & -.486 & .628 \\
1 & Persepsi Kemudahan & .292 & .091 & .289 & 3.218 & .002 \\
Persepsi Kepercayaan & .118 & .137 & .073 & .864 & .390 \\
& Efektivitas & .587 & .107 & .521 & 5.491 & .000
\end{tabular}

a. Dependent Variable: Minat Menggunakan Fintech

T tabel: 1,661

Sumber: Data Primer (2020) diolah dengan SPSS V.20

Berdasarkan hasil penelitian diatas dapat dirumuskan persamaan regresi linier berganda sebagai berikut:

$$
Y=-1,173+0,292 X 1+0,118 X 2+0,587 X 3+e
$$

Nilai konstanta menunjukkan angka $-1,173$. Hal ini mengartikan bahwa variabel minat menggunakan fintech akan mengalami penurunan sebesar $-1,173$ apabila variabel persepsi kemudahan, kepercayaan dan efektivitas sama dengan nol.

Nilai koefisien beta sebesar 0,292 pada variabel persepsi kemudahan mengartikan bahwa jika persepsi kemudahan penggunaan semakin mudah digunakan, mudah dipelajari, mudah untuk berinteraksi dan fleksibel maka minat pelaku UMKM dalam menggunakan financial technology akan meningkat sebesar 0,292. Sedangkan nilai $t$ hitung sebesar 3,218 $>t$ tabel 1,661 dengan tingkat signifikan 0,002 < 0,05. Maka hipotesis pertama terdukung dan menunjukkan bahwa persepsi kemudahan secara signifikan berpengaruh positif terhadap minat pelaku UMKM menggunakan financial technology.

Nilai koefisiensi beta sebesar 0,118 pada variabel kepercayaan tidak memiliki pengaruh positif terhadap minat pelaku UMKM menggunakan financial technology, hal ini terlihat dalam nilai signifikan $0,390>0,05$ dan nilai thitung $0,864<t$ tabel 1,661. Maka hipotesis kedua tidak didukung oleh hasil, hal ini mengartikan bahwa tidak ada pengaruh antara kepercayaan dengan minat menggunakan financial technology.

Nilai koefisien beta sebesar 0,587 pada efektivitas mengartikan bahwa jika efektivitas dapat memberikan efek yang baik, memberikan manfaat dan semakin meningkatkan kinerja pelaku UMKM maka minat menggunakan financial technology akan meningkat sebesar 0,587. Sedangkan t hitung $5.491>t$ tabel 1,661 dengan tingkat signifikan 0,000 $<0,05$. Maka hipotesis ketiga didukung oleh hasil yang artinya pengaruh efektivitas berpengaruh positif terhadap minat pelaku UMKM menggunakan financial technology. 
Berdasarkan hasil penelitian diatas menunjukkan bahwa $\mathrm{F}$ hitung sebesar 60,697 dan $\mathrm{F}$ tabel sebesar 2,698 dengan signifikansi sebesar 0,000 dengan probabilitas $<0,05$. Karena $F$ hitung lebih besar dari $F$ tabel $(60,697>2,698)$ dengan nilai signifikansi lebih kecil dari 0,05 $(0,000<0,005)$ maka dapat diartikan bahwa persepsi kemudahan, kepercayaan dan efektivitas secara bersama-sama berpengaruh terhadap minat menggunakan financial technology.

Tabel.3. Hasil Uji Determinasi $\left(\mathbf{R}^{2}\right)$

\begin{tabular}{rlccc}
\multicolumn{4}{c}{ Model Summary } \\
\hline Model & $\mathrm{R}$ & \multicolumn{4}{c}{ R Square Adjusted R Square Std. Error of the Estimate } \\
\hline 1 & $.809 \mathrm{a}$ & .655 & .644 & 2.605
\end{tabular}

a. Predictors: (Constant), Efektivitas, Kepercayaan, Persepsi Kemudahan

b. Dependent Variable: Minat Menggunakan Fintech

Sumber: Data Primer (2020) diolah dengan SPSS V.20

Bersadarkan tabel diatas dapat diperoleh nilai $R$ square $\left(R^{2}\right)$ yaitu 0,655 . Hal ini menunjukkan bahwa $65,5 \%$ variabel persepsi kemudahan, kepercayaan dan efektivitas berpengaruh terhadap minat menggunakan financial technology, sedangkan 34,5\% lainnya dipengaruhi oleh faktor lain yang tidak termasuk dalam penelitian ini

\section{REKOMENDASI KEBIJAKAN \\ Rekomendasi}

Berdasarkan hasil pengujian data SPSS V.20 sesuai dengan tujuan penelitian ini, maka rekomendasi hasil penelitian ini antara lain:

1) Persepsi kemudahan berpengaruh positif dan signifikan terhadap minat menggunakan financial technologi (fintech) dengan koefisien regresi sebesar 0,292 $(29,2 \%)$ terhadap pelaku UMKM di Kabupaten Bantul.

2) Kepercayaan berpengaruh negatif atau tidak berpengaruh terhadap minat menggunakan financial technologi (fintech) dengan koefisien sebesar $0,118(11,8 \%)$ terhadap pelaku UMKM di Kabupaten Bantul.

3) Efektivitas berpengaruh positif dan signifikan terhadap minat menggunakan financial technologi (fintech) dengan koefisien regresi sebesar 0,587 (58,7\%) terhadap pelaku UMKM di Kabupaten Bantul.

\section{Kebijakan}

Bedasarkan hasil dan interpretasi penelitian ini, maka peneliti memberikan saran sebagaii rekomendasi kebijakan antara lain:

1. Tingkat kemudahan penggunaan aplikasi yang berasal dari financial technologi (fintech) harusnya ditingkatkan menjadi lebih mudah sehingga pengguna akan tertarik untuk menggunakan produk financial technologi (fintech).

2. Tingkat kepercayaan produk financial technologi (fintech) perlu ditingkatkan agar tidak hanya mudah digunakan namun pengguna akan semakin percaya tanpa ragu untuk menggunakan produk financial technologi (fintech). 
3. Efektivitas juga perlu ditingkatkan, semakin efektif penggunaan produk financial technologi (fintech) maka pengguna akan semakin berkeinginan untuk menggunakannya.

\section{DAFTAR PUSTAKA}

\section{Buku}

Jogiyanto, 2007. Sistem Informasi Keperilakuan, Yogyakarta : Andi.

Jurnal

Ajzen, Icck.1991. The Theory of Planned Behavior. Organiztion Behavior and Human Dicision Processes Journal. Vol. 50. No.2: 179-211.

Ardiansyah, Tedy. 2019. Model Financial dan Technology (Fintech) Membantu Permasalahan Modal Wirausahan UMKM di Indonesia. Majalah IImiah Bijak. Vol.16.No.2.pp 158-166.

Asosiasi Penyelenggara Jasa Internet Indonesia (APJII). 2015. Profil Pengguna Internet Indonesia 2014. Pusat Kajian Komunikasi Univesitas Indonesia.

Chuang, Lui, dan Kao. 2016. The Adoption of Fintech Service: TAM Perspective. International Journal of Management and Administrative Science. Vol.3. ISSN : 2225-7225.

Davis, Fred D. 1989. Perceived Usefulness, Perceived Ease of Use, and User Acceptance of Information Technology. MIS Quartely. Vol.13.

Fatichatur, Yuswanto A, 2019. Fenomena Perkembangan Crowdfunding di Indonesia, Universitas Islam Darul'Ulum. Jurnal Ekonika. Vol 4, No.1. 34-46.

Irma Muzdalifah. Inayah Aulia dan Bella Gita, 2018, "Peran Fintech dalam Meningkatkan Keuangan Inklusif pada UMKM di Indonesia" Jurnal Masharif-Syariah Vol. 3, No. 1. Universitas Muhammadiyah Surabaya.

Mayer, R.C., Davis, J.H., Schoorman, F.D. 1995. An Integrative Model of Organizational Trust. Academy of Management Review.

Pamungkas S, 2018. Pengaruh Kepercayaan, Kegunaan dan Kemudahan IT Terhadap Minat Menggunakan Mobile Money T-Cash Studi Pada Mahasiswa Jurusan Perbankan Syariah IAIN Surakarta.

Rosalina dkk. 2015. Aplikasi Crowdfunding Sebagai Perantara Penggalngan Dana Berbasis Website dan Facebook Application. Jurnal Infra Vol. 3 No.2.

Wildan M. 2019. Pengaruh Persepsi Kemudahan Penggunaan, Evektivitas dan Risiko Terhadap Minat Bertransaksi Menggunakan Financial technology (Fintech).

\section{Peraturan}

Peraturan Presiden Nomor 28 Tahun 2016 Tentang Strategi Nasional Keuangan Inklusif yang ditetapkan Presiden Joko Widodo pada 1 September 2016.

Undang-Undang Nomor 20 Tahun 2008 Tentang Usaha Mikro, Kecil dan Menengah.

\section{Website}

https://m.medcom.id/ekonomi/mikro/8N0V8mAk-umkm-dongkrak-pertumbuhan-ekonomiyogyakarta-lampaui-nasional, diakses 27 Oktober 2020. 